\title{
Guo Moruo on Marx and Confucius
}

\author{
Bart DESSEIN*
}

\begin{abstract}
Through the analysis of two of Guo Moruo's literary works--his "Marx Enters a Confucian Temple" published in 1926, and "Confucius Eats" published in 1935-Guo Moruo's assessment of Confucius and Marx is discussed. It is shown how Guo Moruo, although being a self-declared Marxist, kept on adhering to some Confucian principles, and how this attitude of his helps to explain why Guo Moruo, after having been criticized in the "pi Kong pi Lin" campaign, is now, within the revival of Confucianism in the People's Republic of China, being revaluated.
\end{abstract}

Keywords: Guo Moruo, Confucianism, Marxism, "society creation”(Changzao she), Confucian revival

\section{Guo Moruo o Marxu in Konfuciju Izvleček}

Članek na osnovi analize dveh Guo Moruojevih literarnih del, »Marx vstopi v konfucijanski tempelj« (1926) in »Konfucij se prehranjuje« (1935), prikaže Guo Moruojevo ovrednotenje Konfucija in Marxa. Analiza prikaže, da Guo Moruo sledi nekaterim konfucijanskim načelom, četudi je samooklican marksist. To v nadaljevanju pojasnjuje ponovno vrednotenje Guo Moruoja v okviru oživitve konfucianizma v Ljudski republiki Kitajski, čeprav so ga v kampanji »Kritizirati Konfucija in kritizirati Lin Biaota» (Pi Kong pi Lin) močno kritizirali.

Ključne besede: Guo Moruo, konfucianizem, marksizem,»Ustvarjalno društvo« (Chuangzao she), oživitev konfucianizma

\section{Introduction}

According to an internet message placed on the website "Guanchazhe” 观察者 on 28 December 2014, Guo Moruo’s 郭漠若 (birth name Guo Kaizhen 郭開貞;18921978) 1925 story “Makesi jin wenmiao" (马克思进文庙 Marx Enters a Confucian Temple) had, in 2015, become a hotly debated issue, as in that year it was one of

* Bart DESSEIN, Professor, Ghent University,

Belgium.

Email address: bart.dessein[at]UGent.be

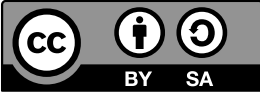


the topics for the examination in political analysis, assigned to potential MA research students (Quanguo shuoshi yanjiusheng zhaosheng kaoshi 全国硕士研究生招生 考试 ). ${ }^{1}$ (see “Makesi jin wenmiao" 2014) The message published on "Guanchazhe" stated that, apart from this text by Guo Moruo, the content of speeches by State President $\mathrm{Xi}$ Jinping 习近平 was also a topic in this examination: more precisely, the test asked how Xi Jinping's saying that, "The lion China has already awakened, but it is a peaceful, lovable, and cultured lion" (Zhongguo zhe tou shizi yijing xing le, dan zhe shi yi zhi hepingde, keaide, wenmingde shizi 中国这头狮子已经醒了, 但 这是一只和平的、可爱的、文明的狮子) should be understood.

Another internet message, published one day earlier on the website "Pengpai Xinwen” 澎看新闻 and reporting on the same examination for potential MA research students, stated that the materials for the students' examination were mainly selected from the Renmin ribao 人民日报. ${ }^{2}$ The message assessed this as a sign that actual politics had become an important aspect of the students' examination on politics. (Zheng 2014) The message mentioned that the examination focused on five topics: (1) the meeting in November 2014 of the World Internet Conference (Shijie hulianwang dabui 世界互联网大会); ${ }^{3}$ (2) the implementation of the policy for the development of the non-state economy and small scale enterprises, summarised as "let big cats and small cats all have their own developmental path" (Rang da xiao mao dou you zoulu 让大猫 小猫都有走路 ); (3) Guo Moruo's text “Marx enters a Confucian Temple” that fuses Marxist thought (sixiang 思想) with China's traditional Confucian thought (sixiang); (4) the rule of the country according to law, as theme of the fourth plenary meeting of the 18th Party Congress; and (5) the question first raised by Montgomery: "Could China become a hegemon once having become strong?"

The present paper discusses Guo Moruo's assessment of Confucius and Marx, and interprets this assessment against the background of the apparent revaluation of Confucianism in contemporary China. This evaluation of Guo Moruo's "fusing" of Marxist "thought" and Confucian "thought" mentioned on the "Pengpai" website is done through the analysis of two of Guo Moruo's texts: his 1925 “Makesi jin wenmiao” 马克思近文庙, and his 1935 “Kongfuzi chifan” (“Confucius Eats” 孔夫子吃饭).

1 This message was originally published in the Renmin ribao, and was reposted on Wenkuwang (2014).

2 Renmin ribao of 5 May, 20 May, 26 May, 24 October, 29 October, and 21 November 2014.

3 The World Internet Conference is also known as Wuzhen Summit 乌镇峰会 (Wuzhen fenghui), and is an annual event, organized by government agencies in China to discuss internet issues and policy. The first of these conferences was held in 2014. 


\section{The 1920s: From a "Literary Revolution" to a "Revolutionary Literature"}

\section{The May Fourth Movement and the Development of Revolutionary Literature}

By 1920 the May Fourth Movement (Wu Si yundong 五四运动) of 1919 had developed in two directions: a politically activist branch, and a cultural and scientific branch. One of the consequences of this was that many radical intellectuals moved to Shanghai, the city where Western influence was most palpable. This also was the city with the most advanced media and editorial culture. Beijing, to quote Brunhild Staiger $(1989,365)$, again became "the new centre of conservatism and tradition, but also the one of scientific research and erudition." These differences between Beijing and Shanghai were also reflected in China's literary scene, that witnessed the creation of a series of literary associations. The two associations that dominated the 1920s were the Society for Literary Research (Wenxue yanjiubui 文学研究会) and the Society Creation (Chuangzao she 创造社). The Society for Literary Research was established in Beijing in 1921 with the purpose of gathering innovative authors, translating foreign literature with a focus on the literature of Asian peoples and oppressed European peoples, and boosting the status of professional writers (ibid.). Most wellknown and established authors were members of this society. The Society Creation was established in July 1921 in Shanghai, i.e., the same month in which the Chinese Communist Party (Zhongguo gongchandang 中国共产党; hereafter CCP) was established, also in Shanghai. Guo Moruo, who, starting in 1918, had studied at the Medical School of Kyūshū Imperial University, but whose greatest interest was in literature, was one of the co-founders of this society. Other illustrious figures such as $\mathrm{Yu}$ Dafu 郁达夫 (1896-1945) and Cheng Fangwu 成仿吾 (1897-1984) were co-founders of Chuangzao she. In 1922, the Chuangzao she decided to publish a journal: Creation Quarterly (Chuangzao jikan 创造季刊). Two other periodicals followed: Creation Weekly (Chuangzao zhoubao 创造周报), which was published from May 1923 to May 1924, and Creation Daily (Chuangzao ri 创造日), of which one hundred issues were published between 21 July and 31 October 1923. These daily issues were attached to the newspaper China Daily (Zhonghua ribao 中华日报). In 1924, a group of younger writers joined the "Society Creation". They started the publication of a new fortnightly newspaper, Deluge (Hongshui 洪水). The presence of these younger writers further radicalized Chuangzao she, which resulted in some of the veteran members of the Society moving to Guangzhou. In 1926, these veteran members transformed the former quarterly journal Chuangzao jikan to a monthly journal Creation Monthly (Chuangzao yuekan 创造月刊), which lasted until January 1929 (Staiger 1989, 366; Lee 2002a, 165).

Whereas the writings of the first four years of the existence of the Chuangzao she, i.e., the period from the foundation of the Society in 1921 to early 1925, had been 
characterized by an influence of Western romanticism and individualism, an influence that is, for example, clearly visible in Guo Moruo's first poetry anthology, titled Goddesses (Nüshen 女神), the events of 30 May 1925 in which the international police in Shanghai opened fire on striking workers (see Schmidt-Glintzer 1999, 526; Lee 2002b, 197), and the rupture between the Nationalists and Communists in April 1927, introduced a major shift in the orientation of the society's writings. From the middle of 1925 onwards, and until the end of the society's existence in 1929, the activities and writings of the members shifted from romanticism and individualism to more socially and politically engaged works (Staiger 1989, 365-66, 372; Schwartz 2002, 137). This change was typified as a transition from a "literary revolution" as characteristic of the early May Fourth Movement, to a "revolutionary literature" by Cheng Fangwu in his article with the same title published in the February 1928 issue of Chuangzao yuekan (see Staiger 1989, 372; Lee 2002b, 197). This shift towards a revolutionary literature that characterized the "junior partners" of Chuangzao she who had gained firm control in Shanghai, resulted in their eviction of Yu Dafu from membership, and their persuasion of Cheng Fangwu and Guo Moruo to use the society's publications as an "ideological stronghold" of Marxism. With the orientation of Chuangzao she having shifted towards "revolutionary literature," the Society joined forces with others such as the Sun Society (Taiyang she 太阳社) who were influenced by the Soviet Union, to, in 1930, form the League of Leftist Writers (Staiger 1989, 372). This was opposed to the Crescent Moon Society (Xinyue she 新月社) that had been established by the poet Xu Zhimo 徐志摩 (1897-1931) in 1923, and of which the majority of members had studied in Britain and the United States and advocated liberalism and literary autonomy, devoid of any class consideration and opposed to proletarian and revolutionary literature (ibid., 373). ${ }^{4}$

\section{Guo Moruo: From an "Individualist" to a "Marxist" Writer}

Judging from a letter Guo Moruo wrote to Cheng Fangwu on 9 August 1924, it was very likely while in Japan, after having read a book written by the Japanese economist Kawakami Hajime 河上肇 (1879-1946), one of the pioneers of Marxist political economy in Japan, that he became a Marxist. (Goldman 1967, xvi; Staiger 1989, 368; Lee 2002b, 197) In this "Guhong - Zhi Cheng Fangwude yi feng xin” (“Letter to Cheng Fangwu” 孤鸿 - 致成仿吾的一封信), Guo Moruo

4 Lu Xun 鲁迅 (1881-1936) who, earlier, had sponsored the publication of a translated text called “Su-e wenyi lunzhan" ("Literary Debates in Soviet Russia” 苏俄文艺论战), by the “Unnamed Society" (Weiming she 未明社) in Beijing, became a leading figure of the “League of Leftist Writers" (see Lee 2002b, 197). 
wrote that he had completely changed his former thinking that was deeply rooted in individualism, and that he had now,

[b]ecome an ardent supporter of Marxism. For the time in which we are living, Marxism is the only precious raft.

[...] 成了个彻底的马克思主义的信徒了! 马克思主义在我们所处 的这个时代是唯一的宝筏。) 5 (Guo Moruo quan ji 1989, 16: 8; quoted in Wang 1992, 224)

Guo Moruo's self-proclaimed conversion to Marxism and his revolutionary zeal were already announced, as it were, in the following statement he made on 18 May 1923 in his "The New Movement of Our Literature" (Womende wenxue xin yundong 我们的文学新运动), on the occasion of the bloodshed that happened when the warlord Wu Peifu 吴佩孚 (1874-1939) sent his troops to besiege the Worker's Union of Jiang'an 江岸 on the Beijing-Hankou railway and slaughtered the unarmed workers and the picketers on 7 February $1923,{ }^{6}$

China's political life is at the verge of breaking down. The imperiousness of the military that resembles wild animals, the disruptive activities of shameless politicians, and the oppression by greedy foreign capitalists, have made the blood and tears of our Chinese people swell to a red stream that resembles the Huanghe and the Yangzi [...]. [Let us] struggle, exchange a repulsive society for a tassel of warriors of valiant mankind.

中国的政治局面已到了破产的地步。野兽般的武人专横，破廉耻的政 客蚌动，贪婪的外来资本家压迫，把我们中华民族的血泪排抑成了黄 河、扬子江一样的赤流。 $[\cdots]$ 奋斗，做个赳赳的人生之战士与丑恶 的社会交缨。 ${ }^{7}$ (Guo Moruo quan ji 1989, 16: 6; quoted in Wang 1992, 213)

$5 \quad$ Also see Schmidt-Glintzer 1999, 515. In this letter, Guo Moruo states that Kawakami Hajime's book Social construction and social revolution (Shehui zuzhi yu shehui geming 社会组织与社会革命) is one of only three books he took along on his voyage to Japan (see Guo Moruo quan ji 1989, 16: 6).

6 By the end of 1922, 16 individual workers' unions had been established along the BeijingHankou railway and the members felt it was necessary to have a federation of unions. Therefore, the preparation commission of the "Federation of Workers Union of Beijing-Hankou Railway" decided to hold the establishment ceremony on February 1, 1923. The workers' intentions were interfered with by warlord $\mathrm{Wu}$ Peifu, who sent his military police to sabotage the hall where the ceremony was scheduled to take place. To protest against Wu's actions, the Federation decided on a major strike on February 4,1923, and relocated its office to Jiang'an, in the city of Hankou. On February 7, Wu Peifu sent his troops to besiege the Worker's Union of Jiang'an and slaughter the unarmed workers and the pickets.

$7 \quad$ Also see Schmidt-Glintzer 1999, 514-15. 
In the same text, he expressed his revolutionary zeal in the following way,

We want to howl like the storm, we want to erupt like a volcano, we want to radically exterminate and incinerate all existing filthiness, to radiate the whole soul, manifest the whole life.

我们要如暴风一样唤号, 我们要如火山一样爆发, 要把一切的腐 败的存在扫落尽, 烧葬尽, 迸射出全部的灵魂, 提呈出全部的生 命。 ${ }^{8}$ (Guo Moruo quan ji 1989, 16: 4; quoted in Wang 1992, 218)

Building on the same comparison, he urges the new literature to be,

[a] literature that resembles the Huanghe and the Yangzi and melts all things foreign into the self.

融化一切外来之物于自我之中 $[\cdots]$ 黄河扬子江一样的文学。 ${ }^{9}(G u o$ Moruo quan ji 1989, 16: 5; quoted in Wang 1992, 218)

Guo Moruo's statements in the above quotations are, on the one hand, exemplary of the May Fourth Movement that wanted to formulate an answer to the dominant West (bring "the disruptive activities of shameless politicians, and the oppression by greedy foreign capitalists" to a halt), but on the other hand also testify to what Shu-mei Shih $(2001,97)$ called the "asymmetrical cosmopolitanism" that characterizes some of the May Fourth literature. With the term "asymmetrical cosmopolitanism," she points to the fact that,

[t] he application of the term "cosmopolitanism" is by definition asymmetrical, depending on the position of the subjects in question. When applied to Third World intellectuals, "cosmopolitanism" implies that these individuals have an expansive knowledge constituted primarily by their understanding of the world (read: the West), but when applied to metropolitan Western intellectuals there is a conspicuous absence of the demand to know the non-West. This "asymmetrical cosmopolitanism" is another manifestation of a Western-dominated world view.

$8 \quad$ Also see Schmidt-Glintzer 1999, 515.

9 Also see Schmidt-Glintzer 1999, 515. This new appeal to literature is in line with the statements Deng Zhongxia 邓中夏 (1894-1933) and Yun Daiying 恽代英 (1895-1931), two members of the Chinese Communist Party, had made in the journal Zhongguo qingnian (Chinese Youth 中国青年): "Literature should be used as a weapon to arouse people's revolutionary consciousness." (see Zhang in Li et al. 1951, 36-49; also see Lee 2002b, 197) 
When, therefore, Guo Moruo calls for the creation of "[a] literature that resembles the Huanghe and the Yangzi and melts all things foreign into the self," he testifies to the conviction that reviving Chinese culture exists in creating a "modern universalism" that would overcome the East-West dichotomy. This had to be done through searching for those elements in the Chinese tradition that have a homologue in the Western tradition. Through this psychological process, the Chinese tradition was presented as of equal value to the Western tradition. Phrased differently: overcoming the West was to be achieved through including the West.

In the above quoted letter to Cheng Fangwu of 9 August 1924, Guo Moruo also gives his opinion on the nature of the new literature:

My opinion about literature has completely changed. I am of the opinion that the problem is not the different -isms with respect to the technical aspect [of literature]. The only problem is the problem of the literature of yesterday, today, and tomorrow. The literature of yesterday are the sacred works that while away the time of the unconscious aristocrats who have come to possess privileged powers in life. [...] The literature of today is our literature, that we now go on the road to revolution. It is our lament because we are suppressed, the cry of a suppressed life, the spell of warriors, the anticipated joy of revolution. The contemporary literature is a revolutionary literature. [...] And what is the literature of tomorrow like? Oh, Fangwu, that is the time and place of transcendental literature you once mentioned. [...] Fangwu, we are on a revolutionary path, our literature can only be revolutionary literature.

我现在对于文艺的见解也全盘变了。我觉得一切伎俩上的主义都不 能成为问题，所可成为问题的只是昨日的文艺，今日的文艺，和明 日的文艺。昨日的文艺是不自觉的得占生活的优先权的贵族们的消 闲圣品 $[\cdots]$ 。今日的文艺，是我们现在走在革命途上的文艺，是我 们被压迫者的呼号，是生命穷促的喊叫，是斗士的咒文，是生命 预期的欢喜。这今日的文艺便是革命的文艺 $[\cdots]$ 。明日的文艺又是 甚么呢? 芳坞哟, 这是你几时说过的超脱时代性和局部性的文艺 $[\cdots]$ 。芳坞哟, 我们是革命途上的人，我们的文艺只能是革命的文 艺。 ${ }^{10}$ (Guo Moruo quan ji 1989, 16: 19-20)

10 On the controversy between Hu Feng 胡风 (1902-1985) and Guo Moruo on popularization and "national form" of the literature (see Fokkema 1965, 24-25). 
In 1926, in Guangzhou, where the Northern Expedition of the Guomindang 国民党 and the CCP against the Northern Warlords was to be launched, Guo Moruo wrote his “Geming yu wenxue” 革命与文学, a text that is now generally regarded as the "manifesto" of the era's revolutionary literature. In this, he argued that genuine literature can only be revolutionary literature, because,

[e]verything that is new, is good; everything that is revolutionary fulfils the need of mankind and constitutes the keynote of social organization. [...] Literature and revolution never stand in opposition but always convert

凡是新的总就是好的，凡是革命的总就是合乎人类的要求、合乎 社会构成的基调的 $[\cdots]$ 。文学和革命是一致的, 并不是两位的。11 (Guo Moruo quan ji 1989, 16: 36-37)

This statement makes clear that Guo Moruo, aligning with the ideas of the May Fourth Movement, saw literature as a vehicle of the revolution.

\section{"Marx Enters a Confucian Temple" (Makesijin wenmiao)}

\section{Background and Personages of "Marx Enters a Confucian Temple"}

It is in the January 11926 issue of Deluge, the "radical" journal of Chuangzao she that had been established in 1924, that Guo Moruo published "Marx Enters a Confucian Temple" ("Makesi jin wenmiao"), a short text he had written a few weeks earlier, on 16 December 1925. (Guo 2017). This contains a fictitious conversation between Marx and Confucius at the Shanghai Confucius Temple, set on 15 October, the day after dingji 丁祭, i.e., the first day of the second and of the eighth month of the lunar calendar, on which sacrifices are brought to Confucius. Confucius, who is accompanied by his disciples Yan Hui 颜回, Zilu 子路, and Zigong 子贡, welcomes Marx in the temple with the famous words "Having a friend who comes from afar, does that not make happy" (Youpeng zi yuan fang lai, bu yi le bu 有 朋自远方来，不亦乐乎 $)$. (Lunyu 1:1,2)

11 Zhongguo xiandai wenxue shi cankao ziliao (Research Materials on the History of Modern Chinese Literature 中国现代文学史参考资料) (in Lee 2002b, 197-98). 


\section{Confucianism as Pre-scientific Marxism}

After this welcome, a conversation develops between Marx and Confucius through the aid of an interpreter. Marx states that he has come to receive instructions, as he has heard that:

[o] ur -ism (womende zhuyi 我们的主义) has already reached your China (nimen Zhongguo 你们中国 ). I hope that it can be realized in your country. However, recently there were a few people who said that my -ism is completely different from your “thought” (sixiang 思想). My -ism therefore has no chance to be realized in China where your "thought" is widespread. That is why I have come to receive instructions from you directly: what is your "thought" eventually like? In which way is it different from my -ism? To which degree is it different? I would like to receive your guidance regarding these questions.

我们的主义已经传到你们中国，我希望在你们中国能够实现，但 是近来有些人说，我的主义和你的思想不同，所以在你的思想普 通着的中国，我的主义是没有实现的可能性。因此我便来直接领 教你：究竟你的思想是怎么样 ? 和我的主义怎样不同 ? 而且不 同到怎样的地步？这些问题，我要深望你能详细地指示。12

Here, we touch upon a first important element to assess Guo Moruo's standpoint: he uses the term sixiang 思想 to denote Confucianism. According to Franz Schurman (1966), "sixiang," "thought," is different from "theory" (lilun 理论). "Theory," according to Franz Schurman, is pure ideology, i.e., it is universal and always applicable. "Thought," on the contrary, is practical ideology, i.e., the practical use of "theory" in concrete circumstances or in a specific time and place. Interpreted in this way, Guo Moruo's denoting of Confucianism as "sixiang" means that, in practice, Confucianism can be replaced by Marxist ideology without effecting the higher "theory," "lilun." ${ }^{13}$ Judging from the continuation of the story, this lilun might be defined as the Chinese essence ( $t i$ 体), as Confucius's answer to Marx's question is the following:

[m]y "thought" has no system (tongxi 统系) because, as you [Marx] knows, when I was living, there was no science (kexue 科学) yet and I am a person who does not understand logics (luoji 逻辑).

12 All quotations from Guo 2017, "Makesi jin wenmiao."

13 The adaptation of Marxism-Leninism to the concrete Chinese situation is, among other things, also evident from the focus on the mass line, the focus on antagonistic (as different from nonantagonistic) contradictions such as the class struggle, the idea of permanent revolution, or the concept of "learning revolution by executing revolution." 
我的思想是没有什么统系的, 因为你是知道的, 我在生的时候还 没有科学，我是不懂逻辑的人。

The evaluation of Confucianism as "pre-scientific Marxism" - and hence of Marxism as logical, "scientific" continuation of Confucianism-is a clear illustration of the phenomenon of "asymmetrical cosmopolitanism" mentioned above: by claiming that both Confucianism and Marxism are "sixiang," they are given the same (universal) value, and this should make it possible that a "modern" China is created based on the "universal" values China shares with the "advanced" West.

\section{The Real System of Pre-Qin Thought}

This is very much in line with what we read in Feng Youlan's 冯友阑 (1895-1991) introduction to the first volume of his famous Zhongguo zhexue shi 中国哲学史 (History of Chinese Philosophy), published in Shanghai between 1931 and 1934,

Logic is a requirement for dialectic discussion, and since most schools of Chinese philosophy have not striven greatly to establish arguments to support their doctrines, there have been few men, aside from those of the School of Names, who have been interested in examining the processes and methods of thinking; and this school, unfortunately, had but a fleeting existence. Hence logic, like epistemology, has failed to be developed in China. [...] Is it true that Chinese philosophy lacks system? As far as the presentation of ideas is concerned, it is certainly true that there are comparatively few Chinese philosophical works that display unity and orderly sequence; therefore it is commonly said that Chinese philosophy lacks system. Nevertheless, what is called system may be divided into two categories, the formal and the real, which have no necessary connection with one another. It may be admitted that Chinese philosophy lacks formal system; but if one were to say that it therefore lacks any real system, meaning that there is no organic unity of ideas to be found in Chinese philosophy, it would be equivalent to saying that Chinese philosophy is not philosophy, and that China has no philosophy. [...] According to what has just been said, philosophy in order to be philosophy, must have real system, and although Chinese philosophy, formally speaking, is less systematic than of the West, in its actual content it has just as much system as does western philosophy. This being so, the important duty of the historian of philosophy is to find within a philosophy that lacks formal system, its underlying real system. (Feng 1953, 1: 3-4) 
This passage in which Feng Youlan accepts that Chinese philosophy lacks the formal finesse of Western philosophy, but claims that the real system of Chinese philosophy is of equal value to that of Western philosophy, is in line with the early twentieth-century claim of the necessity of a Mr. Science (赛先生 Sai xiansheng) and a Mr. Democracy (德先生 De xiansheng) in China: as much as Europe had had to return to (the roots of scientific thinking and democracy of) Greek antiquity to overcome the "darkness" of the Middle Ages, China also had to return to pre-Qin thinking to arise from the ashes of the defunct empire. ${ }^{14}$

Feng Yu-lan's position is also likely to have been influenced by figures such as the American pragmatist John Dewey (1852-1952), under whom he had studied at Columbia University. After John Dewey had, between 1919 and 1921, given a series of lectures at Chinese universities, the majority of those intellectuals who saw scientific progress as the means for China's "renaissance" became advocates of American pragmatism. Pragmatism taught them that philosophy should not only explain and interpret reality, but that it also needed to be able to change reality. This pragmatism also was close to a fundamental characteristic of traditional Confucianism: a concern with the world here (see Rošker 2008, 149-50). Vera Schwarcz (1986) has, in this respect, rightfully pointed to it that intellectuals of the May Fourth Movement not so much longed for a "new Chinese culture" as they longed for a "renewed" culture, a "Chinese Renaissance," an attempt to reshape tradition.

An assessment of Guo Moruo along these lines can be read in a message, published on Tengxunwang 腾讯网 on 29 December 2014, as follows:

Guo Moruo first saw Confucius as "a giant with everlasting life," but later called him "a famous reactionary personage." 15 In the period of May Fourth, against the tide, Guo Moruo respected Confucius, and wrote his [...] text: "Marx enters a Confucian Temple." [...] "Marx enters a Confucian Temple" shows how Guo Moruo respected Confucius all his life. Guo had experienced a Confucian education since his youth, and when he went to Japan to study, he read the works of Wang Yangming after school time. In the period of May Fourth, when the people of the moment were thrown into the stream of “smash down the Confucian shop" (打倒孔家店 dadao Kongjiadian), Guo Moruo continued to call Confucius "a great talent," "a full personage,"“a giant with an everlasting life.” (Qzone 2018) ${ }^{16}$

14 This standpoint is similar with the position of the early 20th century adherents of Radical Confucianism (junxue 君学) (see Hon 2014).

15 See also further.

16 Also see Guo 1998, 22. 
It can in this respect be remarked that it might therefore not be without importance that, in his article "Artists and Revolutionaries" ("Yishujia yu gemingjia" 艺 术家与革命家), published on 4 September 1923, Guo Moruo did not put the same demand on artists as he did on revolutionaries. For Guo Moruo, activists cannot be expected to create propaganda literature, and neither can revolutionary artists be expected to throw bombs. He justifies this position by claiming that all true revolutionary movements are artistic movements, and all zealous activists are real artists; and that all zealous artists who want to change society are real revolutionaries (see Schmidt-Glintzer 1999, 515).

\section{Confucianism and Marxism for the People}

The conversation between Marx and Confucius continues: Confucius does not feel at ease to explain his "thought" as he is afraid that his lack of logic will only confuse Marx. Moreover, so Confucius states, there is not one book of Marx that has already been translated into Chinese-we may recall here that the conversation between Marx and Confucius develops through an interpreter. He therefore invites Marx to start explaining his -ism. Marx agrees, but before explaining his doctrine he wants to first elaborate on the basic premises, the point of departure (chufadian 出发点). Marx thus claims that his “thought" (sixiang)—again, referring to Franz Schurman, one "thought" can be exchanged for another "thought"is not like the doctrines of ordinary religious specialists (zongjiaojia 宗教家). His -ism does not regard the life of human beings in the universe as nihilistic (xuwu 虚无) or as evil (zui'e 罪恶), but, as we happen to live in this world, it is only through exploration (tanqiu 探求) that we can reach the highest joy and that our world can likewise be made suited to our lives. This characteristic, it can be repeated, is parallel to the "this world" orientation of Confucianism. If, so says Marx, this basic premise of his -ism is different from Confucius', it would be useless to continue the conversation.

\section{A Confucian and Marxist Utopian World}

After Zigong has approved the words of Marx, claiming that the aim of Confucianism is in this world, Confucius continues the conversation, stating that their basic premise is indeed the same. This having been made clear, Confucian asks about Marx's utopian world (lixiangde shijie 理想的世界). Marx replies that, according to many people, he is a materialist (wuzhi zhuyi 物质主义) and that, therefore, there are many people who take him for a wild animal that only knows 
eating, and as a person who is devoid of any ideal. In reality, however, so claims Marx, he is a person who envisions a lofty and remote utopian world. His utopian world is one in which everyone can freely and equally develop his or her capacities, in which all people can do what they can without longing for remuneration, in which all people have an ensured livelihood and do not have to be anxious about hunger or cold. This world, so says Marx, is what he calls the Communist society of "From each according to his ability, to each according to his needs" (Ge jin suo neng, ge qu suo xu 各尽所能, 各取所需). When this type of society is realized, would that not be a heavenly kingdom (tianguo 天国) established on earth?

With this, we reach another important point for assessing Guo Moruo's attitude towards Confucianism and Marxism. The enthusiastic answer of Confucius is:

Your utopian society and my world of unity (datong 大同) agree without prior consultation.

你这个理想社会和我的大同世界竟是不谋而和。

whereupon Confucius invites Marx to listen to part of an old text of his that he will recite by heart. The text he recites is the following:

When the big road of virtue was followed, "all-under-heaven" (tianxia 天下) was public good. Functionaries were selected according to their abilities. Their words were trustworthy, and they cultivated harmony. That is why people did not only treat their own relatives as relatives, did not only treat their own children as children, and made sure that elder people had all they needed until the end of their days, that grown-ups had all they needed, that children had all they needed to grow, that widowers and widows, orphans, and sick ones all had what they needed to sustain themselves. They made sure that men had a job, and women had a place where they belonged. They did not allow the harvest to be left in the field, but neither did they want to hoard it for themselves. They disliked that their power was not made useful for others, but neither did they want to use it for themselves. Therefore, bad plans were not put into practice, there were no robbers, thieves, nor traitors. Therefore, outer doors were not closed. This is what is called datong.

大道之行也, 天下为公。选贤与能, 谁信修睦, 故人不独亲其 亲, 不独子其子, 使老有所终, 壮有所用, 幼有所长, 矜寡孤独 废疾者, 皆有所养。男有分, 女有归。货恶其弃于地也, 不必藏 
于己; 力恶其不出于身也, 不必为己。是故谋闭而不兴。盗窃乱 贼而不作，故外户而不闭，是谓大同。(Liji 1988, 120)

and he concludes with the rhetorical question: "Is this not completely in accordance with your utopian world? (这不是和你的理想完全是一致的吗?).

This passage is, of course, the famous part of the seventh chapter "Liyun" 礼运 of the Records of Ritual (Liji 礼记), the Confucian political handbook that was compiled in the third-second century $\mathrm{BCE}$, in which the Confucian concept of datong is explained. This shows that, for Guo Moruo, the Confucian and the Marxist lilun of the ideal society are the same (see Pusey 1983, 34). The convergence of the Confucian and the Marxist utopias is also reminiscent of the interpretation of the datong concept in late imperial and Republican China (see Dessein 2017), and presages the claim by Mao Zedong (1893-1976) when he alluded to the leading role of the CCP in its historical mission of modernizing the Chinese peasants and workers and uniting them in a Communist society:

China can develop steadily, under the leadership of the working class and the Communist Party, from an agricultural into an industrial country, and from a new-democratic into a socialist and communist society, can abolish classes and realize the "great unity" (datong). ${ }^{17}$ (Mao 1961)

Discussing the above part of the chapter "Liyun," Joseph Needham (1958, 167-68) noted that it must have been "a very peculiar historical turn of events that this highly subversive account became embedded in one of the Confucian classics," as passages with the same wording are also found in the Mozi 墨子 and thus point to an original Mohist affiliation of the concept. We do know, however, that Mohist philosophy was among the interests of Chinese Communist thinkers.

Similarities between the Confucian and the Marxist utopian worlds are also mentioned in the concluding section of the story. When Marx continues to delineate the Marxist progress of history, with a gradual exclusion of private property, the state as central unit, and international ideological expansion, Confucius replies that also he is of the opinion that first production should be lifted, after which it will become possible to distribute wealth evenly - a viewpoint we know from the economic chapters of the eclectic Guanzi 官子 that are accepted to be of Mohist affiliation.

17 Notice that the original English text reads "Great Harmony" instead of "great unity" (see also Schram 2002, 411-12). 


\section{"Confucius Eats"}

In the story “Kongfuzi chifan (“Confucius Eats” 孔夫子吃饭), a text Guo Moruo wrote on 3 June 1935, and that first appeared in the journal Zawen 杂文 published in Tokyo (Guo 1935), ${ }^{18}$ we read the following story: Confucius and his disciples had not eaten for seven days. They stayed in a wood just outside of a village. When they arrived there seven days earlier, some of Confucius's disciples went stealing melons from the fields of nearby farmers because they were so thirsty. The day after, the local farmers who had seen them stealing their melons, had encircled them. Because the farmers thought they had been robbed by a group of bandits, they were afraid and did not dare to come closer. The disciples of Confucius also did not dare to do anything. The resulting stalemate explains why they had not eaten for seven days. On the morning of the 8th day, while Confucius was still asleep, Yan Hui took action. He draped a white cloth over the walking stick of Confucius and went towards the farmers. He explained what had happened, and the farmers broke their encircling. They even felt pity for them, and gave Yan Hui some polished rice (baimi 白米) to cook for his master and the other disciples. Having returned to Confucius and the fellow disciples, Yan Hui explained what had happened. Confucius was very happy, but said to Yan Hui: "Did I not tell you that I am taken care of by the old man in heaven?” (我不是早就说过吗? 我 是有天老爷看承的呀。). Yan Hui gathered firewood, and started to cook gruel because he was afraid that, since the lot of them had not eaten for so long, they might not be able to digest a heavy meal. The disciples' anxiety had gone, but some were still afraid that the gruel might contain too little rice. Confucius saw how Yan Hui at a certain moment lifted the lid from the kettle, put his other hand in the pot, took two fingers full of rice out and put them in his mouth. This disrespected Confucius deeply. After all, he was the leader, and leaders should eat first. However, he did not say a word until Yan Hui had finished preparing the gruel and brought the first bowl to Confucius. Confucius wanted to reveal the hypocrisy of Yan Hui, and said, "[Yan] Hui, a while ago, I dreamed of my father. [...] When there is drink and food, one first has to offer it to one's superiors, and only then eat oneself. Would you please help me to offer some food to my father first?" (回 呀, 我刚才梦见了我的父亲。[...] 有饮食要先敬了长上, 然后再吃。你替 我在露天为我的父亲献祭罢。). Yan Hui hurriedly answered, “Sir, today's rice is no good to offer to the gods” (先生, 今天的饭是不好拿来敬神的。). “Why is it no good to offer to the gods?” (为什么不好拿来敬神?) Confucius replied. Yan Hui said, "I have heard the master saying: vessels of millet used in sacrifices should be clean. The gruel of today is not clean; it is no good to offer it to the gods"

18 In December 1936, it was also published in Shiti 豕蹄. 
(我听先生说过 “策盛必洁”, 今天的稀饭不干净, 不好拿来祭神). “Why is it not clean?" (为什么不干净呢), asked Confucius. Yan Hui answered, “A while ago, when I opened the lid, some charcoal ash flew into it. I quickly used my fingers to get it out. However, I burnt my fingers, and therefore, I put them in my mouth...” (刚才我揭开锅盖的时候飞了一团烟渣进去我赶快用指头把它拈 了起来。但丢掉又觉得可喜, 我的指头也惣了, 所以我便送进了口去。). Upon hearing this, Confucius said, "OK, OK, Hui, You are really a sage; even I cannot catch up with you” (好的, 好的, 回呀你实在是一位圣者, 连我都 是赶不上你的。). Having said this, he confessed his suspicion and his testing of Yan Hui to the other disciples. As an afterthought, although well aware that Yan Hui had been lying, Confucius thought: "My respect as a leader has not been hurt” (我的领袖的尊严, 并没有受伤。).

This story is, interestingly, based on one in the Spring and Autumn of the Lü Clan (Lüshi chunqiu 吕氏春秋), a work that was written in the 3rd century BCE, and that was "intended to comprehend every aspect of philosophical thought that bore on the task of government, on the education and role of the ruler, and on the values that the government should practice and teach."19 (Knoblock and Riegel 2000, vii) The original story in the Lüshi chunqiu is, more precisely, found in Book 17, 3.4 ("Employing Technique"; Ren shu 任数). ${ }^{20}$ In the translation by John Knoblock and Jeffrey Riegel $(2000,418)$ it goes as follows:

When Confucius was in straits in the area of Chen and Cai, the broth of greens contained no rice, and for seven days he did not taste any grain, so even during daylight he had to lie down. Yan Hui asked for some rice, obtained it, and prepared it. Confucius observed that Yan Hui reached for something inside the pot and ate it. He pretended that he had not seen it. When after a while the food was cooked, Yan Hui announced it to Confucius and brought out the food. Confucius rose and said, "Just now I dreamed of our late lord. Since this food is pure, I will offer some to him." Yan Hui replied, "That would not be acceptable. A while ago some charcoal ash fell into the pot. Because it is inauspicious to throw food out, I took it out of the pot and drank it." Confucius sighed and said, "What I believed was my eyes, but it appears that my eyes should not be trusted; what I depended on was my mind, but it appears that is insufficient to be depended on. Disciples, take note of this: knowing other

19 Needham $(1958,36)$ values the Lüshi chunqiu as, "extremely important for the scientific aspects of Taoism.”

20 Referring to Lu Xun's Old Things, Newly Edited (Gu shi xin bian故事新编), we can see also this story as a "new edition of an old story." 
people is assuredly not easy."Thus, it is not the knowing that is difficult, but the means by which we know others that is difficult.

孔子穷陈、蔡之间，藜美不糁，七日不尝粒，昼寝。颜回素米， 得而舉之，几熟。孔子望见颜回篗其甑中而食之。孔子佯不见 之。选间, 食熟, 谒孔子而进食。孔子起曰： ‘今者梦见先军, 食洁而后馈”。颜回对曰：‘不可。乡者煤入甑中，弃食不祥， 回篗而饮之’。孔子叹曰：‘所信者目也，而目犹不可信，所恃 者心也，而心犹不足恃。弟子记之，知人固不意矣，。故知非难 也，孔子之所以知人难也。

It is clear that the difference between Guo Moruo's version of the story and the original version is that, for Guo Moruo, it is not the "means of knowledge" that is difficult to know, but (Confucian) knowledge itself. Confucius, and therefore Confucianism, are criticized for being hypocritical.

\section{Appreciating Guo Moruo}

Comparing "Marx enters a Confucian Temple" and "Confucius Eats," it appears that Guo Moruo's assessment of Confucius became increasingly negative. That he became a "convinced Marxist" may explain his appointment as head of the Third Section of the National Military Council's newly created Political Department in charge of propaganda in 1938 (Lee 2002b, 242). The elevated position of Guo Moruo is also evident from his role as chairman of the "National Congress of Literary and Art Workers," held in Beijing in July 1949 (Fokkema 1965, 33-34). Guo Moruo also became Vice-premier of the government from 1949 to $1954 .{ }^{21}$ In an article in the Renmin ribao of 1 July 1956 on the "One Hundred Flowers Movement," Guo Moruo stated that the "goal of the contending schools should be the building of socialism and, ultimately, communism" (see Fokkema 1965, 91).

In contrast to the above, in an interview with a Bulgarian journalist, published in the Renmin ribao on 18 December 1956, Guo Moruo on the one hand stated that,

The policy of "letting the one hundred flowers bloom and the one hundred schools contend" is advanced under the people's democratic

21 Other positions he held were Vice-chairman of the Chinese People's Political Consultative Conference, Chairman of the All-China Federation of Literary and Art Circles, and President of the Academy of Sciences (see Goldman 1967, xvi-xvii). 
dictatorship. This freedom of writing and discussion is a prerequisite to serve the people and does certainly not mean laisser faire without limitations. If the writings and opinions are counterrevolutionary, there should be no freedom for them,

but on the other hand also stated that,

The self-education of the intellectuals cannot be suspended for a moment. They must be allowed at all times to cultivate their own consciousness and will to study Marxism-Leninism in the light of reality, and to foster the spirit of serving the people and national construction with the result that their work will improve. (see Fokkema 1965, 91; italics mine)

The latter statement explains why, in the already quoted assessment of his "Marx Enters a Confucian Temple" in Tengxunwang, we read that when Guo Moruo published his Shi pipan shu 十批判书 (Ten Books of Criticism) in 1945 he "still called Confucius 'following the tide of the changes of then society' ('顺应着当时 的社会变革的潮流'), 'in great line standing at the side of representing the benefit of the people' ('大体上他是站在代表人民利益的方面的'), and 'benevolent' (“仁).” (Yang 2014)22

Guo Moruo's ambiguous position is, among others, corroborated by the fact that in a report called "The Tasks of the Intellectuals in the High Tide of the Socialist Revolution” (在社会主义革命高潮中知识分子的使命 geming Zai shebuizhuyi gaochao zhong zhishifenzide shiming) he submitted to a session of the National Committee of the Chinese People's Political Consultative Conference on January 31,1956 , he advised intellectuals to examine themselves on three questions in the manner of one of the disciples of Confucius, Zeng Can 曾參, i.e., Zengzi. The three questions are: (1) Are we in any way not positive enough in serving the people and socialist construction? (2) Do we really contribute toward the expansion of our ranks and the unity of internal forces? (3) Are we studying Marxism-Leninism and progressive political experience with a high degree of self-consciousness and without negligence? ${ }^{23}$ Guo Moruo's reference to Zengzi may help to explain why he was forced to give a "self-criticism" in 1966, and why he, after Lin Biao 林彪 (1907-1971) had died, became targeted in the “pi Kong pi Lin” 批孔批林 movement because of his position in the Shipipan shu, i.e. his position of "revering Confucianism and [acting] against the law (尊儒反法).”(Yang 2014) During that

22 Also see Guo 1982, 87, 445.

23 Renmin ribao, February 1, 1956. (Cf. Levenson 1958, 136-37; Levenson 1962; also see Fokkema 1965, 58) 
period, Mao Zedong wrote a poem on Guo Moruo, in which he stated that "He (Guo Moruo) is said to be a Communist, but revers Confucius and Laozi” (名曰 共产党，崇拜孔老二). (Yang 2014) Still according to Mao Zedong, “the way Old Guo treats Qin shi huang and the way he treats Confucius are like Lin Biao" (郭老对待秦始皇, 对待孔子那种态度和林彪一样). (ibid.) Soon afterwards, Mao Zedong presented a copy of the Shi pipan shu to Jiang Qing, saying it was "to be used for criticizing” (为批评用的) (see Feng 2004, 315-18).

In the foreword to the revised edition of his Zhongguo shi gao 中国史搞 (Draft of Chinese History), published in 1976, i.e., two years before his death, Guo Moruo explicitly stated that:

In the assessment of Confucius in the original draft of the work, there were serious mistakes. Now, a fundamental revision is done.

原来的稿子中的对于孔丘的评价有严重的错误。这次作了根本的修改。

Comparing this new edition with the first edition of the work, we see that Confucius as a personage who "follows the tide of history," was changed to "a political and ideological representative of the nobility of slave ideology" (日趋没落的奴康 主贵族的政治和思想上的代表), and “a famous reactionary personage” (一个著 名的反动人物) (Guo 1976, 1: 318, 384).

\section{Conclusion}

An analysis of "Marx enters a Confucian Temple" and "Confucius Eats" shows how Guo Moruo developed from being an advocate of a "literary revolution" to an advocate of a "revolutionary literature." This fact notwithstanding, his attitude towards the Confucian tradition remained an ambivalent one. This explains why he was criticized during the "pi Kong pi Lin" movement, and why he later revised his opinion on Confucius.

That the text "Marx enters a Confucian Temple" is now a renewed object of study is an example of the ambivalent attitude that Chinese Communism has vis- $\grave{a}^{-}$ vis the country's Confucian tradition. As such, this issue illustrates what Helwig Schmidt-Glintzer stated, as follows,

China wanted to completely throw away its past, a young generation wanted to open a new page in history, and yet, getting free from the past was not successful, and this was seen as the core problem of China by many (Schmidt-Glintzer 2009, 33). 


\section{References}

Cheng, Fangwu 成仿吾. 1928. “Cong wenxue geming dao geming wenxue 从文 学革命到革命文学, 创造月刊 (From a 'Literary Revolution' to a 'Revolutionary Literature')." Chuangzao yuekan 1 (9), February 1.

Dessein, Bart. 2017. "Yearning for the Lost Paradise: The 'Great Unity' (datong) and Its Philosophical Interpretations." Asian Studies 5 (1): 83-102.

Feng, Xigang 冯锡刚. 2004. Guo Moruode wannian suiyue 郭漠若的晚年岁月 (Guo Moruo's Old Age). Beijing: Zhongyang wenxian chubanshe.

Feng, Yu-lan. 1953. A History of Chinese Philosophy. Vol. I: The Period of the Philosophers (from the Beginnings to Circa 100 B.C.). Translated by Derk Bodde. Princeton: Princeton University Press.

Fokkema, D. W. 1965. Literary Doctrine in China and Soviet Influence 1956-1960. London, The Hague, Paris: Mouton\& Co.

Goldman, Merle. 1967. Literary Dissent in Communist China. Cambridge MA: Harvard University Press.

Guo, Moruo 郭漠若. 1935. “Kongfuzi chifan 孔夫子吃饭 (Confucius Eats).” Zawen 杂文 2 (1), July 15.

—.1976. Zhongguo shi gao 中国史搞 (Draft for a History of China). Beijing: Renmin chubanshe.

-. 1982. Guo Moruo quan ji 郭沫若全集 (Complete Collection of Guo Moruo), vol.2. Edited by Guo Moruo zhuzuo bianji weiyuanhui. Beijing: Renmin chubanshe.

—.1984. “Kongfuzi chifan 孔夫子吃饭 (Confuciaus Eats).” In Zhongguo xiandai zuojia lishi xiaoshuo xuan 中国现代作家历史小说选 (Selection of Historical Novels of Modern Chinese Authors), 47-50. Shanghai: Shanghai shehui kexue chubanshe.

-. 1989. Guo Moruo quan ji 郭沫若全集 (Complete Collection of Guo Moruo), vol.16, edited by Guo Moruo zhuzuo bianji weiyuanhui. Beijing: Renmin chubanshe.

—. 2017. "Makesi jin wenmiao 马克思进文庙 (Marx Enters a Confucian Temple).” Baidu baike 百度百科. Accessed December 12, 2018. https://baike.baidu.com/item/\%E9\%A9\%AC\%E5\%85\%8B\%E6\%80\%9D\%E8\%BF\%9B\%E6 \%96\%87\%E5\%BA\%99.

Guo, Pingying 郭平英, ed. 1998. Shitineiwai 豕蹄内外 (Inside and Outside of the Hoof). Hangzhou: Zhejiang renmin chubanshe.

Hon, Tze-ki. 2014. "Radical Confucianism: The Critique of Imperial Orthodoxy in Guocui xuebao (1905-1911)."In Interpreting China as a Regional and Global Power: Nationalism and Historical Consciousness in World Politics. Politics and Development of Contemporary China, edited by Bart Dessein, 30-43. Houndmills, Basingstoke and Hampshire: PalgraveMacmillan. 
Knoblock, John, and Jeffrey Riegel. 2000. The Annals of Lü Burvei: A Complete Translation and Study. Princeton: Princeton University Press.

Lee, Leo Ou-Fan. 2002a. "Literary Trends: The Quest for Modernity, 1895-1927.”

In An Intellectual History of Modern China, edited by Merle Goldman and Leo Ou-Fan Lee, 142-95. Cambridge: Cambridge University Press.

—. 2002b. "Literary Trends: The Road to Revolution, 1927-1949." In An Intellectual History of Modern China, edited by Merle Goldman and Leo Ou-Fan Lee, 196-266. Cambridge: Cambridge University Press.

Levenson, Joseph R. 1958. Confucian China and its Modern Fate. Berkeley and Los Angeles: University of California Press.

Levenson, Joseph R. 1962. "The Place of Confucius in Communist China." The China Quarterly 12: 1-19.

Liji 礼记. 1988. In Si shu wu jing 四书五经 Four Book and Five Classisc. Vol. 2. Beijing: Zhongguo shudian.

Lunyu 论语. Accessed April 16, 2018. https://ctext.org/analects/xue-er/zhs.

“Makesi jin wenmiao 马克思进文庙 (Marx Enters a Confucian Temple).” 2014.

Guanchazhe, December 28. Accessed October 1, 2018. https://www.guancha. cn/broken-news/2014_12_28_304635.shtml.

Mao, Zedong. 1961. Selected Works of Mao Zedong. Vol. 4. Beijing: Foreign Languages Press. Accessed August 15, 2016. https://www.marxists.org/reference/ archive/mao/selected-works/volume-4/mswv4_65.htm.

Needham, Joseph. 1958. Science and Civilisation in China. Vol. 2: History of Scientific Thought. Cambridge: Cambridge University Press.

Pusey, James Reeve. 1983. China and Charles Darwin. Harvard East Asian Monographs 100. Cambridge: Harvard University Press.

Qzone. 2018. Accessed: 2 April 2018. http://view.news.qq.com/original/legacyintouch/d289.html.

Rošker, Jana S. 2008. Searching for the Way. Theory of Knowledge in Pre-modern and Modern China. Hong Kong: The Chinese University Press.

Schmidt-Glintzer, Helwig. 1999. Geschichte der chinesischen Literatur. Von den Anfängen bis zur Gegenwart. München: C. H. Beck.

—. 2009. Chinas Angst vor der Freibeit. Der lange Weg in die Moderne. München: Verlag Beck.

Schram, Stuart. 2002. "Mao Tse-Tung's Thought from 1949-1976." In An Intellectual History of Modern China, edited by Merle Goldman and Leo Ou-fan Lee, 267-348. Cambridge: Cambridge University Press.

Schurman, Franz. 1966. Ideology and Organization in Communist China. Berkeley, CA: University of California Press.

Schwarcz, Vera. 1986. The Chinese Enlightenment: Intellectuals and the Legacy of the May Fourth Movement of 1919. Berkeley CA: University of California Press. 
Schwartz, Benjamin I. 2002. "Themes in Intellectual History: May Fourth and After." In An Intellectual History of Modern China, edited by Merle Goldman and Leo Ou-Fan Lee, 97-141. Cambridge: Cambridge University Press. Shih, Shu-mei. 2001. The Lure of the Modern, Writing Modernism in Semicolonial China, 1917-1937. Berkeley, Los Angeles and London: University of California Press.

Staiger, Brunhild. 1989. "Littérature et art." In La Chine au XXe siècle: D’une Révolution à l'autre 1895-1949, edited by Marie-Claire Bergère, Lucien Bianco and Jürgen Domes, 357-81. Paris: Fayard.

Tengxunwang 腾讯网 (Tencent Holdings Limited). Accessed April 2, 2018. http:// view.news.qq.com/original/legacyintouch/d289.html.

Wang, Wenying 王文英. 1992. Guo Moruo wenxue zhuan lun 郭沫若文学传论 (Commentaries on the Literature of Guo Moruo). Ürümqi: Xinjiang Renmin Chubanshe.

Wenkuwang 文库网 (Library Site). 2014. Guanchazhe 32, December 28, 2014. Accessed October 1, 2018. http://www.wenku1.com/news/913141B12CF4A85E.html.

Yang, Jintao 杨津涛. 2014. “Makesi jin wenmiao' beihou de bolan 马克思进文 庙” 背后的波澜 (The Wave Behind the 'Marx Enters a Confucian Temple').” Tengxun wang shouye 289, December 29, 2014. http://view.news.qq.com/original/legacyintouch/d289.html.

Zhang, Bilai 张毕来. 1951. "Yi jiu er san nian 'Zhongguo Qingnian' jige zuozhede wenxue zhuzang 一九二三年 “中国青年” 几个作者的文学主张 (The Literary View of Some Authors from 'Chinese Youth' in 1923).” In Zhongguo xin wenxue shi yanjiu 中国新文学史研究 (Study of the History of New Chinese Literature), edited by Li Helin 李何林et al., 36-49. Beijing: Xin jianshe zazhishe.

Zheng, Zhizu 郑志祖. 2014. “Makesi jin wenmiao 马克思进文庙 (Marx into the Temple of Literature)” Pengpai xinwen wang, December 27, 2014. Accessed October 1, 2018. https://www.thepaper.cn/newsDetail_forward_1289320.

Zhongguo xiandai wenxue shi cankao ziliao 中国现代文学史参考资料 (Research Materials on the History of Modern Chinese Literature). 1959. Edited by Beijing shifan daxue Zhongwen xi xiandai wenxue jiaoxue gaige xiaowu (Peking Normal University, Chinese Literature Department, Contemporary Literature Teaching Reform Group). 3 vols. Beijing: Gaodeng jiaoyu. 